\title{
PEMBUATAN TURBIN MIKROHIDRO TIPE CROSS-FLOW SEBAGAI PEMBANGKIT LISTRIK DI DESA BUMI NABUNG TIMUR
}

\author{
Mafrudin ${ }^{1)}$, Dwi Irawan'). \\ Jurusan Teknik Mesin Universitas Muhammadiyah Metro ${ }^{1,2)}$ \\ Jl. Ki Hajar Dewantara No. 116 Kota Metro (0725) 42445-42454 \\ Email : Mafrudin72@yahoo.co.id
}

\begin{abstract}
Abstrak
Krisis energi yang terjadi di dunia saat ini telah menarik perhatian para peneliti untuk menemukan sumbersumber energi baru yang lebih murah, yang tersedia dalam jumlah yang besar. Pembangkit Listrik Tenaga Mikrohidro (PLTMH) merupakan salah satu solusi yang dapat digunakan untuk mengatasi masalah ini. Turbin cross-flow, merupakan salah satu jenis turbin yang sering digunakan untuk PLTMH. Dalam penelitian ini merencanakan turbin air tipe cross-flow yang diaplikasikan pada air pembuangan perusahaan pembuatan tepung tapioka. Air pembuangan tersebut merupakan air limbah yang sudah melalui proses pengendapan, pemupukan dan pemeriksaan yang kemudian dialirkan kesungai dengan debit rata-rata $0,04 \mathrm{~m}^{3} / \mathrm{s}$ dengan ketinggian diatas permukaan air sungai lebih dari $2 \mathrm{~m}$. Dengan debit dan ketinggian tersebut air pembuangan memilki daya yang cukup besar yang kemudian digunakan untuk memutar turbin air. Pada penelitian ini bertujuan untuk mengetahui spesifikasi turbin, daya yang dihasilkan turbin, efisiensi turbin dan transmisi serta daya listrik yang dihasilkan generator. Metode yang dilakukan dalam penelitian ini yaitu studi pustaka, pengamaan secara langsung atau observasi, perencanaan dan pembuatan turbin serta pengujian. Pada tahap perencanaan yaitu menentukan dimensi turbin berdasarkan sumber daya air pada lokasi penelitian dan proses perhitungan. Pada tahap pengujian yaitu melakukan pengujian turbin yang telah dibuat. Pengujian yang dilakukan yaitu pengujian daya turbin dan daya listrik generator.Turbin air cross-flow memiliki spesifikasi yaitu lebar runner $0,1524 \mathrm{~m}$, diameter luar runner $0,48 \mathrm{~m}$, diameter dalam runner $0,32 \mathrm{~m}$, jarak antar sudu $0,083 \mathrm{~m}$, tebal nozzle $0,04 \mathrm{~m}$, jari-jari sudu $0,078 \mathrm{~m}$ dan jumlah sudu yaitu 20 sudu. Dari hasil pengujian turbin cross-flow didapatkan daya turbin yaitu 236,82 Watt, efisiensi mekanik turbin yaitu $30 \%$ dan daya listrik yang dihasilkan 162 Watt.
\end{abstract}

Kata kunci: Turbin air, Cross-flow, Daya.

\section{PENDAHULUAN}

Krisis energi yang melanda dunia saat ini telah menarik perhatian para peneliti untuk menemukan sumber-sumber energi baru yang lebih murah, yang tersedia dalam jumlah yang besar. Hal ini berkaitan dengan semakin banyak dan meningkatnya pemakaian penggunaan energi. Kebutuhan energi di Indonesia saat ini masih didominasi oleh energi yang berbasis bahan bakar fossil, seperti minyak bumi dan batu bara. Pembangkit Listrik Tenaga Mikrohidro (PLTMH) merupakan salah satu solusi yang digunakan untuk mengatasi masalah ini.

Pemilihan jenis turbin air dalam PLTMH disesuaikan dengan debit air, dan ketinggian (head). Turbin air adalah mesin konversi energi yang berfungsi untuk merubah/mengkonversi energi potensial (head) yang dimiliki oleh air ke bentuk energi mekanik pada poros turbin. Turbin air cross-flow adalah salah satu turbin air dari jenis turbin aksi (impulse turbine).
Pada penelitian ini akan dirancang turbin cross-flow dengan pendekatan nilai efisiensi maksimum yang selanjutnya akan dievaluasi kinerja turbin ini secara teoritis agar didapatkan hasil rancangan turbin yang optimal. Dalam perencanaan turbin air cross-flow ini akan aplikasikan pada air pembuangan perusahaan pembuatan tepung tapioka yang berada di RT 02 / RW 01 desa Bumi Nabung Timur atau lebih dikenal dengan desa Tulung Sluang..

Air pembuangan yang berasal dari perusahaan pembuatan tepung tapioka yang berada di desa Bumi Nabung Timur merupakan air limbah yang sudah dilakukan proses pengendapan dengan sistem kolam dan sudah dikakukan proses pemupukan serta proses pemeriksaan (audit) sehingga dapat dipastikan air limbah atau air pembuangan tersebut sudah tidak berbahaya dan aman baik bagi tumbuhan maupun hewan. Setelah melalui beberapa proses tersebut, kemudian air limbah (air pembuangan) 
dibuang kesungai secara kontinyu (terus menerus), meskipun saat kemarau air limbah tersebut tetap mengalir. Adapun debit air pembuangan tersebut rata-rata $40 \mathrm{liter} / \mathrm{s}$ atau sekitar $0,04 \mathrm{~m}^{3} / \mathrm{s}$ dan ketika musim penghujan debit air pembuangan tersebut akan meningkat. Letak kolam air pembuangan berada pada ketinggian (head) lebih dari $2 \mathrm{~m}$ diatas permukaan air sungai.

Dengan debit yang cukup besar dan ketinggian (head) lebih dari $2 \mathrm{~m}$ maka air pembuangan tersebut memiliki energi yang cukup besar jika dimanfaatkan untuk menggerakkan turbin air yang kemudian digunakan untuk memutar generator dan menghasilkan listrik, namun selama ini air pembuangan tersebut hanya terbuang sia-sia dan belum termanfaatkan sama sekali.

Atas dasar pertimbangan tersebut, maka penulis akan merancang turbin air tipe cross-flow yang nantinya akan diaplikasikan sebagai pembangkit listrik mikrohidro. Spesifikasi turbin sangat berpengaruh terhadap daya yang diihasilkan turbin. Adapun spesifikasi turbin yang sangat berpengaruh terhadap daya yang dihasilkan turbin diantaranya yaitu diameter dan lebar runner turbin. Dengan diameter dan lebar runner yang sesuai dengan debit dan ketinggian air maka akan didapatkan efisiensi turbin yang maksimal

\section{LANDASAN TEORI}

\section{Sejarah Turbin Air}

Turbin air dikembangkan pada abad 19 dan digunakan secara luas untuk tenaga industri untuk jaringan listrik. Sekarang lebih umum dipakai untuk generator listrik. Turbin kini dimanfaatkan secara luas dan merupakan sumber energi yang dapat diperbaharukan. Kincir air sudah sejak lama digunakan untuk tenaga industri. Pada mulanya yang dipertimbangkan adalah ukuran kincirnya, yang membatasi debit dan head yang dapat dimanfaatkan. Perkembangan kincir air menjadi turbin modern membutuhkan jangka waktu yang cukup lama. Perkembangan yang dilakukan dalam waktu revolusi industri menggunakan metode dan prinsip ilmiah. Mereka juga mengembangkan teknologi material dan metode produksi baru pada saat itu.
Kata "turbine" ditemukan oleh seorang insinyur Perancis yang bernama Claude Bourdin pada awal abad 19, yang diambil dari terjemahan bahasa Latin dari kata "whirling" (putaran) atau "vortex" (pusaran air). Perbedaan dasar antara turbin air awal dengan kincir air adalah komponen putaran air yang memberikan energi pada poros yang berputar. Komponen tambahan ini memungkinkan turbin dapat memberikan daya yang lebih besar dengan komponen yang lebih kecil. Turbin dapat memanfaatkan air dengan putaran lebih cepat dan dapat memanfaatkan head yang lebih tinggi (Poernomo Sari, S., dan Fasha Ryan. 2012)..

\section{Pengertian Turbin Air}

Turbin secara umum dapat diartikan sebagai mesin penggerak mula di mana energi fluida kerja yang digunakan langsung memutar roda turbin, fluida kerjanya yaitu berupa air, uap air dan gas. Dengan demikian turbin air dapat diartikan sebagai suatu mesin penggerak mula yang fluida kerjanya adalah air. (Arismunandar, W., 2004 : 1). Berbeda yang terjadi pada mesin torak (motor bakar), pada turbin tidak terdapat bagian mesin yang bergerak translasi. Bagian turbin yang berputar dinamai rotor (runner pada turbin cross-flow) atau roda turbin, sedangkan bagian yang tidak berputar dinamai stator atau rumah turbin. Roda turbin terletak didalam rumah turbin dan roda turbin memutar poros daya yang menggerakkan atau memutar bebannya (generator). Kalau ditinjau dari daya yang dihasilkan turbin air, maka dikenal istilah Pembangkit Listrik Tenaga Mikrohidro (PLTMH) yang maksudnya adalah turbin air yang dapat menghasilkan daya kurang dari 100 $\mathrm{kW}$ dan sumber airnya relatif kecil.

\section{Prinsip Kerja Turbin Air}

Pada roda turbin terdapat sudu yaitu suatu konstruksi lempengan dengan bentuk dan penampang tertentu, air sebagai fluida kerja mengalir melalui ruang diantara sudu tersebut, dengan demikian roda turbin akan dapat berputar dan pada sudu akan ada suatu gaya yang bekerja. Gaya tersebut akan terjadi karena ada perubahan momentum dari fluida kerja air yang mengalir diantara sudunya. Sudu hendaknya dibentuk sedemikian rupa sehingga dapat terjadi 
perubahan momentum pada fluida kerja air tersebut (Arismunandar, W., 2004:2).

\section{Klasifikasi Turbin Air}

Turbin air mengubah energi potensial air menjadi energi mekanis. Energi mekanis diubah dengan generator listrik menjadi tenaga listrik. Berdasarkan prinsip kerja turbin dalam mengubah energi potensial air menjadi energi mekanis (momentum fluida kerjanya), turbin air dibedakan menjadi dua kelompok yaitu turbin impuls dan turbin reaksi (Arismunandar, W., 2004:67).

Diagram klasifikasi turbin air dapat dilihat pada gambar dibawah ini.

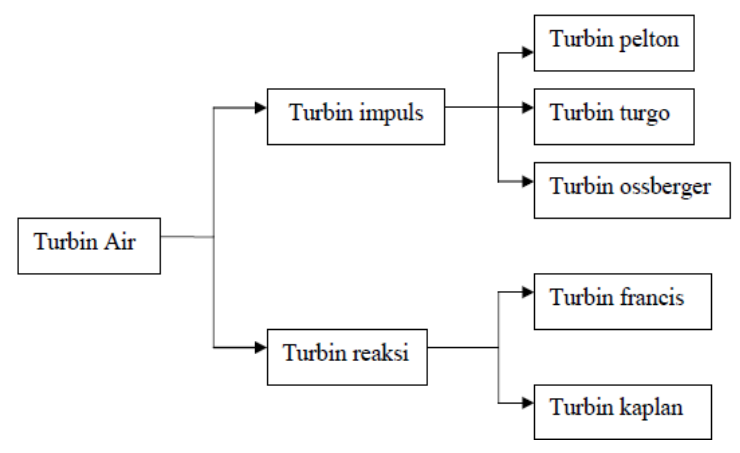

Gambar 1. Diagram klasifikasi turbin air

\section{Turbin Cross-flow}

Turbin tipe ini dibuat pertama kali di Eropa. Nama cross-flow diambil dari kenyataan bahwa air melintasi kedua sudu gerak atau runner dalam menghasilkan putaran (rotasi). Sedangkan nama Banki (dari Hungaria) dan Mitchell (dari Austria) adalah nama ahli teknik yang mengembangkan prinsip - prinsip turbin tersebut yaitu turbin ini dilengkapi dengan pipa hisap, dan sebagai akibatnya daya yang dihasilkan turbin, proses kerja dan randemen turbin menjadi lebih baik. Turbin cross-flow ini mempunyai arah aliran yang radial atau tegak lurus dengan sumbu turbin. Turbin ini mempunyai alat pengarah sehingga dengan demikian celah bebas dengan sudu-sudu di sekeliling roda hanya sedikit. Karena itu pada keadaan beban penuh perputarannya roda terjadi sedikit kemacetankemacetan, yang menimbulkan sedikit tekanan lebih. Turbin cross-flow terdiri dari tiga bagian utama yaitu roda jalan, alat pengarah dan rumah turbin. Dalam aplikasinya turbin cross-flow baik sekali digunakan untuk pusat tenaga air yang kecil dengan daya kurang lebih $750 \mathrm{~kW}$. Tinggi air jatuh yang bisa digunakan diatas $1 \mathrm{~m}$ sampai $200 \mathrm{~m}$ dan kapasitas antara $0,02 \mathrm{~m}^{3} / \mathrm{s}$ sampai 7 $\mathrm{m}^{3} / \mathrm{s}$ (Dietzel, F., 1993).

Komponen - komponen utama konstruksi turbin cross-flow adalah sebagai berikut :

1. Rumah Turbin

2. Alat Pengarah (distributor)

3. Roda Jalan

4. Penutup

5. Katup Udara

6. Pipa Hisap

7. Bagian Peralihan

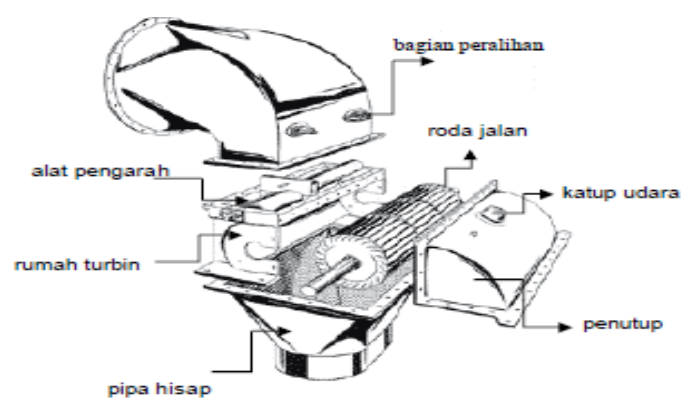

Gambar 2. Konstruksi Turbin Ossberger atau Turbin Cross-flow

Salah satu komponen utama pada turbin cross-flow yaitu runner.

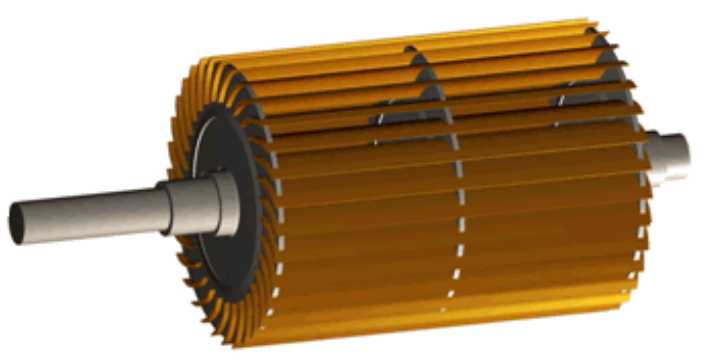

Gambar 3. Runner Turbin Cross-flow

\section{Perencanaan Pipa Pesat}

Pipa saluran mempunyai fungsi untuk mengalirkan air dari penampungan air atau bak penenang menuju ke turbin atau disebut pipa 
pesat. Sebelum menentukan dimensi pipa pesat hendaklah mencari data-data yang diperlukan dalam perencanaan pipa pesat. Adapun data yang menunjang dalam perencanaan pipa pesat yaitu luas pemampang air yang keluar dari sebuah bak penenang sebelum masuk pada pipa pesat. Dimana luas penampang keluaran air tersebut diperoleh dari survei dan hasil pengukuran di lokasi akan dilakukannya penelitian. Dengan pengukuran secara langsung diharapkan dapat memperoleh data yang sesuai dengan kondisi di lapangan yang kemudian digunakan untuk menentukan dimensi pipa pesat.

Setelah mengetahui luas penampang keluaran air, maka untuk mencari diameter pipa digunakan persamaan berikut.

$$
\mathrm{A}=\pi / 4 . \mathrm{d}^{2} \text { (Arismunandar, W.,2004) }
$$

maka

$$
\begin{aligned}
& \mathrm{d}=\sqrt{\frac{4 \cdot A}{\pi}} \\
& \text { Dimana: } \\
& \mathrm{d}=\text { Diameter pipa }(\mathrm{m}) \\
& \mathrm{A}=\text { Luas penampang saluran }\left(\mathrm{m}^{2}\right)
\end{aligned}
$$

\section{Perencanaan Runner Turbin Cross-flow}

Perencanaan atau perhitungan parameter turbin cross-flow menggunakan persamaanpersamaan Mockmore (dalam Pratilastiarso J., and Hesti S., 2012:316) yaitu sebagai berikut.

1. Diameter luar (D) dan lebar sudu (L) runner turbin

$$
\mathrm{LD}=\frac{2,62 Q}{\sqrt{H}}
$$

2. Diameter dalam runner turbin $\left(D_{1}\right)$

$$
\mathrm{D}_{1}=2 / 3 \mathrm{D}
$$

3. Jarak antar sudu (K)

$$
\mathrm{K}=0,174 \mathrm{D}
$$

4. Ketebalan semburan nozzle $(\mathrm{M})$

$$
\mathrm{M}=0,22 \frac{Q}{L \sqrt{H}}
$$

\section{Jari-jari kelengkungan sudu $\left(\mathrm{r}_{1}\right)$

$$
r_{1}=0,163
$$

6. Jumlah sudu (N)

$$
\mathrm{N}=\frac{\pi \cdot D}{K}
$$

Daya air yang digunakan $\left(\mathbf{P}_{\text {air }}\right)$

$$
\mathrm{P}_{\mathrm{air}}=\text { p.g.H.Q } \quad \text { (Dietzel, F., 1993) }
$$

\section{Daya yang dihasilkan turbin $\left(\mathbf{P}_{\mathbf{t}}\right)$}

Dengan,

$$
\mathrm{P}_{\mathrm{t}}=\mathrm{T} . \omega \text { (Arismunandar, } W ., 2004 \text { ) }
$$

$$
\begin{aligned}
& \mathrm{T}=\mathrm{F} \cdot \mathrm{D} / 2 \\
& \text { atau }
\end{aligned}
$$$$
\mathrm{T}=\mathrm{F} . \mathrm{r} \quad \text { (Arismunandar, W.,2004) }
$$

Dan,

$$
\omega=2 \pi \mathrm{n} / 60 \text { (Arismunandar, W.,2004) }
$$

\section{Efisiensi mekanik turbin $\left(\boldsymbol{\eta}_{\mathbf{t}}\right)$}

$$
\mathrm{P}_{\text {turbin }}=\mathrm{P}_{\text {air }} \cdot \eta_{\mathrm{t}} \text { (Dietzel, F., 1993) }
$$

Maka

$$
\eta_{\mathrm{t}}=\frac{P_{\text {turbin }}}{P_{\text {air }}}
$$

\section{Kecepatan Keliling Turbin}

$$
\left.\mathrm{v}=\frac{2 \cdot \pi \cdot n}{60} \cdot \mathrm{r}_{\text {run }} \text { (Dietzel, } F ., 1993\right)
$$

\section{Daya yang dihasilkan generator $\left(P_{g}\right)$}

$$
\mathrm{P}_{\mathrm{g}}=\mathrm{V} \text {. I }
$$

(Poernomo dan Fasha, 2012)

\section{Efisiensi Transmisi}

$$
\mathrm{P}_{\mathrm{g}}=. \mathrm{P}_{\mathrm{t}} \cdot \eta_{\mathrm{g}} \cdot \eta_{\text {trans }}
$$

( Asief Rosyidin, M., et all. 2012)

Maka

$$
\eta_{\text {trans }}=\frac{P_{g}}{\eta_{g} \cdot P_{t}}
$$

\section{METODE PENELITIAN}

Metode penelitian adalah langkah dan prosedur yang akan dilakukan dalam pengumpulan data atau informasi. Dalam penelitian ini data atau informasi yang diperlukan dapat diperoleh melalui beberapa metode yaitu:

1. Penelitian Kepustakaan (studi pustaka)

2. Pengamatan secara langsung atau observasi Data yang diambil diantaranya:
a. Debit air (Q)
b. Ketinggian (head)
c. Luas penampang keluaran air.

3. Interview

4. Dokumentasi

5. Pengolahan data dan Perhitungan untuk menentukan jenis/spesifikasi peralatan mekanikal dan elektrikal yang akan dipakai dalam perencanaan PLTMH.

6. Prosedur pembuatan
a. Tahap perencanaan
b. Tahap pelaksanaan

7. Proses pengujian

a. Pengujian daya turbin

b. Pengujian daya listrik 


\section{Perhitungan Dan Pembahasan}

Berdasarkan survei dan pengukuran serta pengumpulan data dari lokasi dimana akan dilakukan penelitian didapatkan data yang dapat digunakan dalam perencanaan ukuran atau dimensi turbin cross-flow yang akan dibuat. Adapun data yang diperoleh yaitu debit air 0,04 $\mathrm{m}^{3} / \mathrm{s}$ dengan ketinggian (head) $2 \mathrm{~m}$, atas dasar sumber daya alam yang ada dan proses perhitungan maka diperoleh hasil rancangan atau spesifikasi turbin air cross-flow yaitu lebar runner turbin $0,1524 \mathrm{~m}$, diameter luar runner turbin $0,48 \mathrm{~m}$, diameter dalam runner turbin 0,32 $\mathrm{m}$, jarak antar sudu 0,083 m, tebal nozzle 0,04 m, jari-jari sudu $0,078 \mathrm{~m}$ dengan jumlah sudu 20 sudu.

Pengujian daya yang dihasilkan turbin dilakukan secara manual yaitu dengan melakukan pengujian torsi dengan pembebanan atau pemberian pengaruh massa terhadap putaran turbin. Dimana pengujian dilakukan dengan menggunakan 2 neraca pegas yang diikat dengan sebuah tali tambang yang kemudian tali tambang tersebut dikaitkan pada puli dengan diameter 25 $\mathrm{cm}$ atau jari-jari $12,5 \mathrm{~cm}$ yang berada pada poros turbin, dimana gaya gesek antara puli pada turbin dengan tali tambang diabaikan. Dari hasil pengujian torsi pada putaran tertentu maka dapat diketahui daya yang dihasilkan turbin. Berdasarkan hasil pengujian dan perhitungan diperoleh daya yang dihasilkan turbin kurang lebih 236,82 Watt.

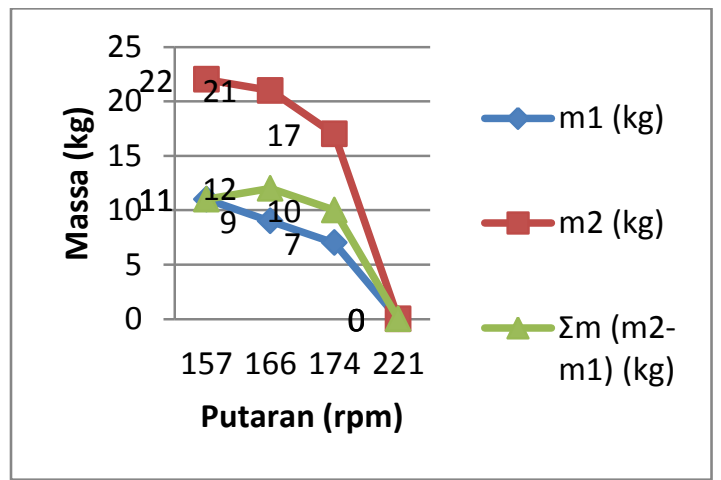

Gambar 4. Grafik hubungan pengaruh massa pada pengujian torsi terhadap putaran turbin

Dari Gambar 4. Hubungan pengaruh massa pada pengujian torsi terhadap putaran turbin dapat diketahui pengaruh besarnya pemberian massa terhadap putaran turbin. Dimana sebelum dilakukan pembebanan putaran turbin mencapai $221 \mathrm{rpm}$ namun ketika dilakukan pembebanan putaran turbin menurun seiring dengan penambahan beban. Sehingga dapat disimpulkan bahwa semakin besar beban yang diberikan maka putaran turbin semakin menurun.

Dari hasil pengujian daya yang dihasilkan turbin dengan membandingkan dengan daya air yang digunakan maka dapat diketahui efisiensi turbin air cross-flow yang telah dibuat. Dari hasil perhitungan yang telah dilakukan dapat diketahui bahwa efisiensi mekanik turbin yaitu $30 \%$ dengan kecepatan keliling maksimal runner $5,55 \mathrm{~m} / \mathrm{s}$.

Pembuatan turbin air cross-flow ini diaplikasikan sebagai pembangkit listrik mikrohidro dimana daya yang dihasilkan dengan kapasitas yang rendah. Adapun daya listrik yang dihasilkan dari pembangkit listrik mikrohidro yang memanfaatkan air pembuangan perusahaan pembuatan tepung tapioka yaitu 162 Watt dengan efisiensi transmisi $83,4 \%$. Selain pengujian daya listrik dari generator juga dilakukan pengujian pengaruh pemakaian daya listrik terhadap putaran turbin. Adapun pengujian dilakukan untuk mengetahui hubungan antara pemakaian daya listrik terhadap putaran turbin.

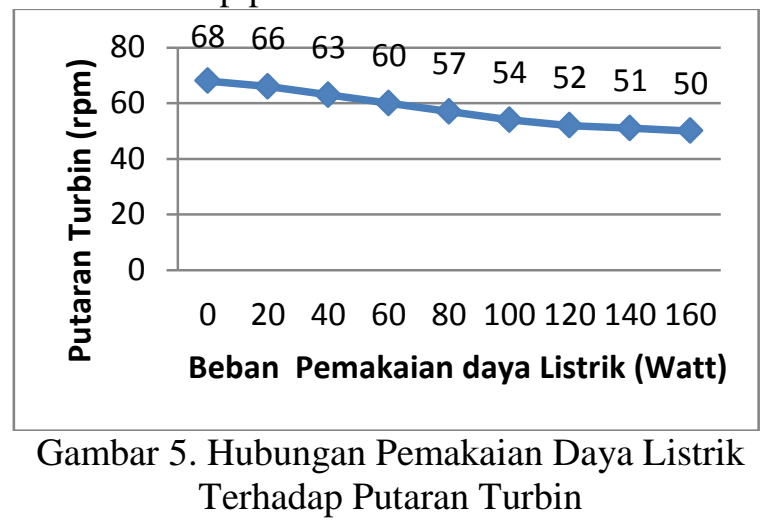

Dari Gambar 5. dapat diketahui pengaruh dari pemakaian daya listrik terhadap putaran turbin. Pada saat daya listrik dari generator tidak digunakan putaran turbin yaitu $68 \mathrm{rpm}$, namun pada saat daya listrik dari generator digunakan dengan kelipatan 20 Watt putaran turbin semakin menurun seiring dengan bertambahnya pemakaian daya listrik. Dengan demikian dapat disimpulkan bahwa semakin besar daya listrik dari generator yang digunakan maka putaran turbin semakin menurun 


\section{KESIMPULAN}

Berdasarkan data yang diperoleh dari hasil penelitian dan pengujian dapat disimpulkan bahwa:

1. Spesifikasi turbin cross-flow yang telah dibuat yaitu:
a. Lebar runner $0,1524 \mathrm{~m}$
b. Diameter luar runner $0,48 \mathrm{~m}$
c. Diameter dalam runner $0,32 \mathrm{~m}$
d. Jarak antar sudu $0,083 \mathrm{~m}$
e. Tebal nozzle $0,04 \mathrm{~m}$
f. Jari-jari sudu $0,078 \mathrm{~m}$
g. Jumlah sudu yaitu 20 sudu

2. Daya yang dihasilkan turbin air crossflow yaitu 236,82 Watt

3. Efisinsi mekanik turbin air cross-flow yaitu $30 \%$

4. Daya listrik yang dihasilkan generator

\section{DAFTAR PUSTAKA}

1. Ade Larasati, Andi., Hirman, Syukri., Syamsul Arifin, A. pembuatan Dan Pengujian Pembangkit Listrik Tenaga Mkrohidro Turbin Banki Daya 200 Watt. Jurnal Mekanikal, Volume 03 Nomor 012012.

2. Arismunandar, Wiranto. Penggerak Mula Turbin. ITB. Bandung: 2004.

3. Asief Rosyidin, M., Sutikno, Djoko., Sugiarto. Pengaruh Bukaan Guide Vane Terhadap Unjuk Kerja Turbin Cross-flow Tipe C4-20 Pada Instalasi PLTMH Andungbiru. Jurnal Teknik Mesin 2012.

4. Bluwprint. Pengolahan Energi Nasional 2005-2025. Jakarta: 2005.

5. Dietzel, F., Sriyono, Dakso. Turbin Pompa Dan Kompresor. Erlangga. Jakarta: 1993.

6. Kementrian Energi Dan Sumber Daya Mineral. Statistik Energi Baru dan Terbarukan. Jakarta: 2009.

7. Mockmor, CA dan Freet Merryfield. "The Banki Water Turbin", Oregon State College, Bulletin Series, No.25, 1984.(dalam Pratilastiarso, Joke, Hesty Sholihah, Fifi. 2012)
8. Poernomo Sari, S., dan Fasha, Ryan. Pengaruh Ukuran Diameter Nozzle 7 Dan 9 mm Terhadap Putaran Sudu Dan Daya Listrik Pada Turbin Pleton. Jurnal Teknik Mesin, 2012.

9. Pratilastiarso, Joke., dan Hesti Sholihah, Fifi. Evaluasi Teoritis Unjuk Kerja Turbin Crossflow. Jurnal Politeknik Elektronika, 2012. 